MANCHESTER

1824

넌

Economics

Discussion Paper Series

EDP-1018

\title{
Risk as determinant of income and cross-border pricing of multi-national enterprises
}

Stefan Lutz

Daniel Kleinfeldt

August 2010

Economics

School of Social Sciences

The University of Manchester

Manchester M13 9PL 


\title{
Risk as determinant of income and cross-border pricing of multi-national enterprises *
}

\author{
Stefan Lutz ${ }^{* *}$ and Daniel Kleinfeldt
}

\section{August 2010}

International taxation rules for multi-national enterprises (MNEs) prescribe that international prices for goods and services between different subsidiaries - and therefore incomes of these subsidiaries - must be comparable to those set between independent international firms for the purpose of taxation. These rules also prescribe that risk should be accounted for in pricing and income. Since current practice of price comparisons does not yet fully allow accounting for risk, prices and in turn earnings and taxation may be distorted. We analyze a panel of about 160,000 European manufacturing, wholesale and retail trade firms for the years 1992 to 2007 in order to establish to what extent earnings do take risk into account. Risk measured by earnings volatility emerges as one major determinant of income. When earnings are set in relation to invested capital, risk emerges as the only stable determinant of income. Results indicate that both MNEs and independent firms regularly account for risk as a major determinant of income when pricing international goods and services.

JEL classification: F2, K2, L0, M4

Keywords: MNE, transfer pricing, OECD guidelines, risk, income

\footnotetext{
${ }^{*}$ The views expressed in this paper are those of the author and do not necessarily reflect those of the institutions they are affiliated with. Any information presented is of a general nature and does not address individual circumstances of any particular person or entity. The authors would like to thank Yves Herve, Matthias Kaut, Paul Mason as well as participants at the $85^{\text {th }}$ WEAI Conference in Portland, OR, on 30 June 2010 for helpful comments and suggestions, however, the usual disclaimer applies. Financial support by the International Centre for Economic Research (ICER), Torino, Italy, and by the Spanish Ministry of Education and Science (Grant No. ECO2008-06191) is gratefully acknowledged.

${ }^{* *}$ Dr. Stefan Lutz, stefan.lutz@manchester.ac.uk, is a Research Fellow at the University of Manchester, UK.
} 


\section{Introduction}

International restructurings by globally acting enterprises have become a common occurrence in the wake of accelerating globalization and lead to increasing global relocations of economic activities. Besides resource cost and infrastructure, the taxation regime, through its effects on institutional hurdles for business development on one hand and on international pricing on the other hand, is an important determinant of the geographical development of globalization. While OECD taxation rules prescribe that risk should be accounted for when determining international prices for goods and services between - and therefore incomes of - different subsidiaries of multi-national enterprises (MNEs), current empirical practice of price and income comparisons does not yet fully allow for risk as a major determinant.

So far, empirical price comparisons of income and transfer prices within MNEs are conducted by analyzing descriptive statistics of sets of comparable firms and transactions derived from socalled benchmark studies. These studies do not take individual account of differences in the amount of risk assumed by different individual comparables within a set. Nevertheless, theoretical considerations as well as previous research suggest that there is a systematic relationship between international pricing and earnings and risks assumed when measured as volatility in net earnings. This research analyses the relationship between expected net earnings and volatility of net earnings of firms as well as the influence of other factors with respect to function performed, product, industry, geography, age of the firm, independence and others.

Data analyzed comes from the Amadeus firm-level data base and spans a panel of European manufacturing, wholesale and retail trade firms for the years 1992 to 2007 . Results are used to draw conclusions with regard to intermediate product pricing within European multi-nationals. Risk measured by earnings volatility emerges as one major determinant of pricing. Risk emerges as the only stable determinant of pricing when earnings are set in relation to capital employed. 
The remainder of the paper is structured as follows. Section 2 introduces the economic and institutional background, the resulting research questions posed here, as well as the hypotheses to be investigated. Section 3 describes the data used. Section 4 presents the general modeling and summarizes the results. Section 5 concludes. Statistical and econometric results are presented in the appendix.

\section{Background and research questions}

Profitability of a particular enterprise can generally be assessed from an investor's perspective by observing profits as a return on some measure of capital invested. Following contemporary capital market theory, risk-adverse investors take the level of risk involved in the investment into account when determining what amount of return they expect on a risky investment. In applied modern corporate finance theory the remuneration for the risks associated to an investment is measured by the so called Equity Risk Premium (ERP). One of the standard conclusions of this theory is that an adequate remuneration for the risks taken is a function of the volatility of the returns on the equity invested. Based on historical financial markets data, the relation between the volatility of the returns on the capital invested on the one hand and the ERP with which capital markets remunerate the assumption of risk on the other hand can be identified. Empirical analyses show that the ERP paid by the capital market for the assumption of risk corresponds to a multiple of the standard deviation of the Returns on Equity (RoE). ${ }^{1}$

While these empirical results are derived from data on investments in financial markets, the principles should also apply when an investor finances an enterprise directly, i.e. the investor would expect that the profits to be derived from the equity invested in a particular enterprise

\footnotetext{
${ }^{1}$ See, e.g., Damodaran (2008).
} 
are an adequate remuneration for the invested equity - given the particular level of risk involved. As a consequence, the pricing of an enterprises goods or services must be set such that the resulting profits can be expected to adequately remunerate the firm's investors for the risks they have taken in financing the enterprise.

While this should hold for any enterprise, it should also be true for individual subsidiaries of MNEs. Consequently, transfer prices, i.e. prices for goods and services between different subsidiaries within MNEs, should also be set such that the subsidiaries' investors are adequately remunerated for the risks they have taken in financing the subsidiaries.

International taxation rules do principally assert the comparability of economic conditions, pricing and profits of independent enterprises with subsidiaries of MNEs and the resulting principle applied to the evaluation of international transfer prices by national tax authorities is known as the arm's length standard. ${ }^{2}$ OECD taxation rules in also prescribe that risk should be accounted for when determining international prices for goods and services between different subsidiaries of MNEs. ${ }^{3}$

The OECD principles also directly imply that risk should be accounted for when evaluation resulting profits of such subsidiaries of MNEs, since the adequacy of transfer prices is most commonly measured by comparisons of profit-level indicators, such as profit after taxes, between independent firms and comparable subsidiaries of MNEs.

So far, empirical price comparisons of transfer prices within MNEs are conducted by analyzing descriptive statistics of sets of comparable firms and transactions derived from socalled benchmark studies using individual firm data from a publicly available database.

\footnotetext{
${ }^{2}$ The arm's length standard for the assessment of transfer prices remains consensus among the OECD member states. See para 1.6 and 1.12 of the OECD guidelines (OECD (1995/2001)).

${ }^{3}$ Compare para 1.27 of the OECD guidelines (OECD (1995/2001)). See also OECD (2008) for new OECD considerations regarding business restructurings changing corporate risk profiles, as well as Baumhoff/Puls (2009) and Werra (2009) for recent discussions.
} 
While these studies use a variety of selection criteria in order to ensure comparability of the final set of independent firms to the tested subsidiary of a $\mathrm{MNE}^{4}$, they do not specifically account for differences in the amount of risk assumed by different individual comparable firms within a set beyond controlling in a general way for risk in the selection process itself. ${ }^{5}$

Applicability and limitations of benchmark studies have been discussed widely in the literature. ${ }^{6}$ Some of the traditional limitations of the benchmark approach have their source in prior data limitations. Given the vastly increased volume and quality of data available, the influence of risk on individual firms' profitability - as well as that of every other selection criterion commonly used in benchmark analyses - can now also be identified and quantified with the use of econometric panel-data methods. ${ }^{7}$

The research presented here aims to empirically test the following hypotheses about the role of risk on individual firms’ profitability.

(1) Risk measured as volatility of profits is a major determinant of firms’ profits.

(2) Risk measured as volatility of returns on capital invested or employed is the only remaining determinant of firms’ return on capital in the long run.

\footnotetext{
${ }^{4}$ In practice, the search for a comparable set of independent firms is done by identifying independent companies which predominantly carry out the function to be tested (such as manufacturing or wholesale trade), taking other aspects like geographic origin, particular business or industry, company's maturity and size into consideration. Comparables searches by use of databases are internationally widely accepted and also acknowledged by the German Federal Fiscal Court and the German fiscal authorities. See, e.g., BFH Judgment as of October 10, 2001 - I R 1043/00 published in the German Federal Tax Gazette 2004 II p. 171. See also German Federal Ministry of Finance Circular Letter as of April 4, 2005 - IV B 4 - S 1341 - 1/05 published in the German Federal Tax Gazette 2005 I p. 570.

${ }^{5}$ For a typical example of the steps and results of a benchmark search, see Table 1 in the appendix.

${ }^{6}$ See, .e.g., Endres/Oestreicher (2005), Oestreicher/Vormoor (2004), Oestreicher/Duensing (2005). At the same time, other literature more and more addresses innovative ways of incorporating risk considerations into transfer pricing, e.g., Kaut et al. (2007), Faß/Lutz (2009), Kornetzki (2007), Vögele/Lutz (2007).

${ }^{7}$ Compare, Peter (2008) for a comprehensive survey of available data commonly used for European benchmark studies.
} 


\section{The Data}

The empirical analysis is based on data from the AMADEUS ${ }^{8}$ "Very large, large and medium sized companies” database Update No. 180 - September 2009 (DVD-ROM) as well as all previous database versions since 1995.

The latest database update used for the analysis contains information on 2,031,019 companies. From these, all about 160,000 firms contained in the industry codes for manufacturing, retail and wholesale trade where selected (NACE 2 codes 10-32, 45, 46, 47) and corresponding data for the years 1995 to 2009 (as far as available) was compiled.

Data collected comprises the following variables ${ }^{9}$ : BvD ID number ${ }^{10}$, Company name, Country, Trade description (English), Trade description (original language), Immediate shareholder - type, name and percentage of direct ownership, Independence indicator, Industry code and description (NACE Rev.2), Subsidiary - percentage of ownership, Date of incorporation, Active/Inactive, Consolidation code, Operating revenue, Cost of goods sold, Other operating expenses, Operating profit/loss, EBIT, Profit/loss before tax, Profit/loss after tax, Current assets, Working capital, Shareholders funds.

\footnotetext{
${ }^{8}$ The Amadeus database published by Bureau van Dijk Electronic Publishing is a comprehensive, pan-European database containing financial information on public and private companies in 41 European countries. Emphasis is placed on annual financial statements.

These data have been standardized in Amadeus in order to enable comparisons between companies, both nationally and internationally.

A standard company report includes 23 balance sheet items, 25 profit and loss account items and 26 ratios, descriptive information including trade description and activity codes (NACE 1.1, NACE 2, NAICS or UK SIC, US SIC can be used across the database) as well as ownership information.

The Amadeus database is generally used by transfer pricing specialists all over Europe to verify the arm's length character of transfer prices by traditional benchmarking studies. The use of the Amadeus database for such benchmarking studies is generally accepted by European fiscal authorities.

${ }^{9}$ A full list of variables used is given in Table 2 in the appendix. Summary statistics are provided in Table 3.1.

${ }^{10}$ Bureau van Dijk’s unique ID number per enterprise.
} 
In addition, trade descriptions as well as industry descriptions were screened in order to generate additional dummy variables for the functions manufacturing ${ }^{11}$, wholesale ${ }^{12}$, retail ${ }^{13}$, service $^{14}$, and $R \& D^{15}$ activities.

Furthermore, immediate shareholder and independence variables were screened to create an Independence dummy variable according to the standard benchmark selection criteria. ${ }^{16}$

For each country, a separate dummy variable was constructed. Countries (country variables) in the data set are: Denmark, Estonia, Finland, France, Germany, Greece, Iceland, Ireland, Latvia, Liechtenstein, Lithuania, Malta, Moldova, Netherlands, Poland, Portugal, Russian_Fed, Sweden, CH, Ukraine, UK.

Lastly, data on general macroeconomic developments and climate were taken from the Ifo Institute's collection of European economic indices as well as from Eurostat via the European Central Bank. These comprise indices for European economic climate ${ }^{17}$, European capacity utilization $^{18}$, and European production. ${ }^{19}$

\footnotetext{
${ }^{11}$ Dummy variable set to " 1 " if industry code between 1000 and 3299 or if company description contains at least one of the terms manufact*, manufact*, producti*, Producti*.

${ }^{12}$ Dummy variable set to " 1 ” if if industry code between 1000 and 3299 or if company description contains at least one of the terms Wholesal*, wholesal*, whole sal*, Whole sal*.

${ }^{13}$ Dummy variable set to " 1 " if industry code between 1000 and 3299 or if company description contains at least one of the terms Retail*, retail*, end custom*, end consum*.

${ }^{14}$ Dummy variable set to "1" if company description contains at least one of the terms repair*, service*, traini*, consul*.

${ }^{15}$ Dummy variable set to " 1 ” if company description contains at least one of the terms research*, develo*, design*, engineer*.

${ }^{16}$ An enterprise is categorized as independent, when either the Independence Indicator variable is A+, A, or A- or the immediate shareholder is an individual or the enterprise is employer or manager owned.

${ }^{17}$ Index data on European economic climate were taken from http://www.cesifo-group.de (http://www.cesifogroup.de/link/wes-zeitreihen-euro-2009q4.xls, Wirtschaftsklimaindikator Euroraum, Index R1).

${ }^{18}$ Capacity utilization data were taken from the Bundesbank, series YJW244, capacity utilization in manufacturing, Euro zone (16), in percent, http://www.bundesbank.de/statistik/statistik_zeitreihen.php?lang=de\&open=\&func=row\&tr=YJW244.
} 


\section{Modeling and results}

Given the panel data available and the economic hypotheses presented, a regression model takes the following generalized form:

$$
y_{i, t}=\alpha+\mathrm{BF}_{i}+\Gamma G_{i, t}+\Delta M_{t}+\varepsilon_{i, t}+\eta_{i}
$$

where the dependent variable $y_{i, t}$ is a profit level indicator (e.g. profits after taxes or return on shareholder funds) of company $i$ in period $t$;

$F_{i}$ is a vector of determinants specific to firm i but invariant over time (such as country, industry, date incorporated);

$G_{i, t}$ is a vector of determinants that may vary between firms and also over time (e.g., $R \& D$ expenditure, functions performed, income volatility, and industry);

$M_{t}$ is a vector of period-specific determinants that affect all firms in the same manner (e.g. global economic factors);

$\varepsilon_{i, t}$ is an idiosyncratic error term that may vary between firms and also over time;

and $\eta_{i}$ represents unobserved heterogeneity across firms (i.e., company specific random effects).

This general specification allows for either random-effects or fixed-effects modeling, where the random or fixed effects are firm-specific components. The more general approach is to allow for random firm-specific effects; the case where these effects are fixed, that is determinate constants instead of random variables, is a special sub-case. In particular, the random-effects

\footnotetext{
${ }^{19}$ Industrial production index data were taken from http://sdw.ecb.europa.eu/ (Eurostat, Industrial Production Index, series STS.M.I5.W.PROD.2C0000.4.000, STS.M.I5.W.PROD.NS0040.4.000, and

STS.M.I5.W.PROD.NS0050.4.000, short-term statistics, monthly, fixed composition, working-day adjusted).
} 
estimation procedure is still consistent, even if fixed effects are present, whereas a fixed-effects procedure is biased if the true model contains only random effects. ${ }^{20}$

The data available contains several firm-specific, time-invariant variables that can be assumed to capture a significant part of present fixed effects (e.g. country, NACE2, functional dummies, etc.). Hence a random-effects specification seems to be a priori more appropriate. Therefore, the majority of results presented are based on random-effects estimations.

In order to test the two hypotheses introduced in the previous section, two sets of regressions are run.

The first set of regressions in Models (1) to (4) analyses profits after taxes (PaT) while the second set of regressions in Models (5) to (7) analyzes after-tax returns on shareholder funds (RoEbaT). Since the various profit variables are highly correlated with each other and the various capital variables are also highly correlated with each other ${ }^{21}$, the results presented within these seven models are generally robust to some degree regardless of the profit variable or the capital variable chosen. Thus the random-effects specification of Model (2) is given by:

(2) $\quad \mathrm{PaT}_{i t}=\alpha+\gamma_{1} \mathrm{PaT} \_s 3_{i t}+\eta_{i}+\varepsilon_{i t}$

The fixed-effects specification of Model (7) is then given by:

(3) RoEbaT_a3 $3_{i t}=\alpha+\beta_{i}+\gamma_{1} R o E b a T \_s 3_{i t}+\varepsilon_{i t}$

The instrumental-variables random-effects specification of Model (10) is then given by:

$$
\text { RoEbaT_a3 } 3_{i t}=\alpha+\gamma_{1} \overline{R o E b a T \_s 3_{i t}}+\eta_{i}+\varepsilon_{i t}^{22}
$$

\footnotetext{
${ }^{20}$ See, e.g., Greene (2002), Hausman (1978). Fixed-effects regression may be chosen over a random-effects specification, if the Hausman test on random effects is rejected.

${ }^{21}$ See Table 3.2 for correlation coefficients of various profit and capital variables.

${ }^{22}$ The variable RoEbaT_s3 in equation (4.a) is instrumented using two lags of RoEbaT in equation (4.b).
} 


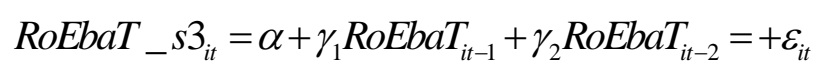

The other seven models are set up accordingly. The results of all model regressions are summarized in Tables reported 4.1, 4.2 and 4.3 in the appendix; the details to each regression are reported in Tables 5.1 to 5.10 .

The suffix_a3 denotes a 3-year moving average whereas_s3 denotes a 3-year moving standard deviation. Both variables are designed to capture the "longer-term” relationship between risk and profit or return, respectively.

The results on profit after tax are reported in Table 4.1 in the appendix. They basically confirm that risk measured as 3-year moving standard deviation ${ }^{23}$ has a strong significant effect on profit after tax. Given the high correlation between operating profit, profit before tax, and profit after tax, these results are also true for these other profit variables.

In Model (1), which takes contemporary profit after tax as dependent variable, variables on capital are significant as are three of the functions indicators. However, neither the year nor the dummies for independence and for active firms, or the date of incorporation appear to have a significant effect on profit levels. ${ }^{24}$ A comparison of Models (1) and (2) indicates that about 40 percent of the total variation in the data explained by model (1) can be explained by the risk variable alone.

Models (3) and (4) take the 3-year average of profit after tax as dependent variable in order to capture the longer-term relationship between risk and profit. As expected, both models have a significantly higher explanatory power. In addition, besides risk, other explanatory variables, such as the year, the retail function indicator, the date of incorporation, and one of the

\footnotetext{
${ }^{23}$ Alternative estimations using 5-year averages and standard deviations basically confirm all the results presented here.

${ }^{24}$ Alternative estimations indicate that most country dummies are not significant in a wide variety of model specifications.
} 
macroeconomic indicators become significant. A comparison of Models (3) and (4) indicates that about 50 percent of the total variation in the data explained by model (3) can be explained by the risk variable alone.

The results on return on capital invested (shareholder funds) are reported in Tables 4.2 and 4.3 in the appendix. They basically confirm that risk measured as 3-year moving standard deviation ${ }^{25}$ has a strong significant effect on return on capital (see models (6) and (7)) while virtually no other variable remains significant. ${ }^{26}$ Given the high correlation between shareholder funds, current assets, and working capital, these results are also true for return on capital measures using these other capital variables. In fact the risk variable alone accounts for over 90 percent of the variation in return to capital, whereas all other variables combined cannot even explain one percent of the variation (since their parameter estimated are all not significantly different from zero). The results remain when endogeneity of the risk measure is taken into account (see models (8) to (10)).

Parameter estimates indicate that the return on capital should increase by about three quarters of a percent for every percentage point increase in risk measured as standard deviation, so the resulting ERP is 0.75 percent for any percent increase in risk. ${ }^{27}$

\footnotetext{
${ }^{25}$ Alternative estimations using 5-year averages and standard deviations basically confirm all the results presented here.

${ }^{26}$ The only exception here is the NACE Rev.2 industry code which appears to be a determinant on the 10 percent significance level. Several alternative estimations, e.g. including yearly dummies, basically confirm the results presented here, i.e. most possible variables with exception of the risk variable appear insignificant.

${ }^{27}$ Damodaran (2008) reports yearly historical US stock returns and treasury bill rates for 1928 to 2007. Calculating the resulting equity risk premia and estimating their relationship on return volatility results in somewhat lower parameter estimates of about 0.33 to 0.55 . However, since stock market data reports include market value of capital invested and the Amadeus firm-level data analyzed here include book values, the results are not directly comparable.
} 


\section{Conclusions}

The research presented here aimed to empirically test hypotheses about the role of risk on individual firms' profitability. The results presented provide strong evidence that risk measured by profit volatility in fact is a major determinant of profits and therefore of international pricing for independent firms and multi-national enterprises alike.

Furthermore, when earnings are set in relation to invested capital, risk emerges as the only stable determinant of return on capital. It follows that risk together with the amount of capital invested appear to be the only significant determinants of pricing.

Results thus indicate that both independent firms and MNEs regularly account for risk as well as the amount of capital invested as the major determinants of pricing international goods and services.

\section{Literature}

Baumhoff, H. \& M. Puls (2009). „Der OECD-Diskussionsentwurf zu Verrechnungspreisaspekten von ,Business Restructurings' - Analyse und erster Vergleich zu den deutschen Funktionsverlagerungsregeln nach §1 Abs 3 AStG“, IStR 18(3), 73-108.

Damodaran, A. (2008), “Equity Risk Premiums (ERP): Determinants, Estimation and Implications”, Stern School of Business.

Endres, D. and Oestreicher, A. (2005). Dokumentation der Angemessenheit von Verrechnungspreisen _ Eine empirische Untersuchung zum Einsatz von Unternehmensdatenbanken, Fachverlag Moderne Wirtschaft.

Faß, A. and S. Lutz (2009). “Co-Entrepreneur-Modell”, Controlling, 21(11), 591-597. 
Greene, W.H. (2002). Econometric Analysis (5th Edition), Prentice Hall.

Hausman, J. A. (1978). „Specification Tests in Econometrics“, Econometrica, Vol. 46, No. 6.

Kaut, M., M. Freudenberg \& G. Foth (2007). „Verrechnungspreismethodik: Ausgleichzahlungen als Instrument der Ergebnissteuerung bei Routineunternehmen“, Betriebsberater, 62(31), 1665-1669.

Kornetzki, T. (2007). “Wertorientierte Steuerung ausländischer Tochtergesellschaften”, Controlling, 12, 679-687.

OECD (1995/2001). „Transfer Pricing Guidelines for Multinational Enterprises and Tax Administrations“.

OECD (2008). „Transfer Pricing Aspects of Business Restructurings: Discussion Draft for Public Comment“, published 19 Sept. 2008.

Oestreicher, A. and Vormoor, C. (2004). "Verrechnungspreisanalyse mit Hilfe von Unternehmensdatenbanken - Vergleichbarkeit und Datenlage“, $\underline{\text { IStR, }} 2004$ Heft 3.

Oestreicher, A. and Duensing, M. (2005). “Eignung von Unternehmensdatenbanken zur Bestimmung der Verrechnungspreise an deutsche Vertriebsunternehmen“, IStR, 2005 Heft 4.

Peter, S. (2008). Theoretische und empirische Analyse von Margenvergleichen zur Bestimmung und Überprüfung von Verrechnungspreisen. Freiburger Dissertationsreihe.

Vögele, A. \& S. Lutz (2007). Guidelines address migrating business“, International Tax Review, 32, 35-40.

Werra, M. (5 Feb 2009). „Verrechnungspreise bei der Restrukturierung internationaler Unternehmensgruppen - Zum Stand der Diskussion in der OECD“, IStR 18(3), 73-108. 


\section{Appendix}

Table 1. Example of a typical sampling process for benchmarking

\begin{tabular}{|c|c|c|c|}
\hline Step & Search Criterion & Description of Search Criterion & Search Result \\
\hline 1 & $\begin{array}{l}\text { No. of companies in the } \\
\text { database }\end{array}$ & $\begin{array}{l}\text { AMADEUS Update No. } 180 \text { - September } \\
2009 \text { (DVD-ROM) }\end{array}$ & $2,031,019$ \\
\hline 2 & Geographical Screen & EU 27 & $1,639,762$ \\
\hline \multirow[t]{3}{*}{3} & \multirow{3}{*}{$\begin{array}{l}\text { Standard industrial } \\
\text { classification code search } \\
\text { (Nace Rev. 2) }\end{array}$} & NACE Rev. 2 & \\
\hline & & 4646 - Wholesale of pharmaceutical goods & \\
\hline & & & 7,273 \\
\hline 4 & Keyword Search & $\begin{array}{l}\text { Keyword search to exclude irrelevant } \\
\text { companies }\end{array}$ & 6,541 \\
\hline 5 & Year of incorporation & $\begin{array}{l}\text { Incorporation date before and including } \\
2002\end{array}$ & 5,504 \\
\hline 6 & Active/Inactive Screen & Exclusion of inactive companies & 5,192 \\
\hline \multirow[t]{2}{*}{7} & \multirow[t]{2}{*}{ Independence Screen } & $\begin{array}{l}\text { Excluding a company if a corporate } \\
\text { shareholder owns } 25 \% \text { or more of the shares }\end{array}$ & \\
\hline & & $\begin{array}{l}\text { Excluding a company if it owns } 25 \% \text { or } \\
\text { more of any company }\end{array}$ & 1,138 \\
\hline 8 & $\begin{array}{l}\text { Availability of Financial } \\
\text { data }\end{array}$ & $\begin{array}{l}\text { Financial data available for at least two } \\
\text { years in the years } 2005 \text { to } 2008\end{array}$ & 773 \\
\hline 9 & SG\&A to Turnover & $\begin{array}{l}\text { Excluding a company if SG\&A-to-turnover } \\
\text { ratio is smaller than } 15 \% \text { or higher than } 25 \%\end{array}$ & 167 \\
\hline 10 & Functional Screening & $\begin{array}{l}\text { Companies are excluded from the set if they } \\
\text { perform different functions using business } \\
\text { descriptions in English or native language }\end{array}$ & 81 \\
\hline 11 & Product Screening & $\begin{array}{l}\text { Companies are excluded from the set if } \\
\text { products are significantly different using } \\
\text { business descriptions in English or native } \\
\text { language }\end{array}$ & 29 \\
\hline 12 & Internet Screen I & $\begin{array}{l}\text { Companies are excluded from the set if they } \\
\text { perform different functions according to } \\
\text { their websites; companies without web } \\
\text { presence remain in the set }\end{array}$ & 19 \\
\hline \multirow[t]{2}{*}{13} & Internet Screen II & $\begin{array}{l}\text { Companies are excluded from the set if they } \\
\text { perform different functions according to } \\
\text { their websites; companies without web } \\
\text { presence are excluded }\end{array}$ & 6 \\
\hline & $\begin{array}{l}\text { Set of potentially } \\
\text { comparable Companies }\end{array}$ & & 6 \\
\hline
\end{tabular}

Source: AMADEUS Database 
Table 2. List of variables

\begin{tabular}{|c|c|}
\hline Variable & Definition \\
\hline $\mathrm{BvD}$ & Firm ID number (numeric) \\
\hline Year & Year \\
\hline BvDEP_ID_number & BvD ID number (alphanumeric) \\
\hline Company_name & Company name \\
\hline Country & Country \\
\hline Trade_Eng & Trade description (English) \\
\hline Trade_Local & Trade description (original language) \\
\hline ImSharHold_Type & Immediate shareholder - type \\
\hline ImSharHold_Name & Immediate shareholder - name \\
\hline ImSharHold_Pct_Own & $\begin{array}{l}\text { Immediate shareholder -percentage of direct } \\
\text { ownership }\end{array}$ \\
\hline Indep_Ind & Independence indicator \\
\hline NACE2 & Industry code (NACE Rev.2) \\
\hline NACE2_Descr & Industry description (NACE Rev.2) \\
\hline Subs_Pct_Own & Subsidiary - percentage of ownership \\
\hline Date_Incorp & Date of incorporation \\
\hline Active & Active/inactive \\
\hline Cons__Code & Consolidation code \\
\hline OpRev & Operating revenue, EUR thousand \\
\hline COGS & Cost of goods sold, EUR thousand \\
\hline OpExp & Other operating expenses, EUR thousand \\
\hline OpProfit & Operating profit/loss, EUR thousand \\
\hline EBIT & EBIT, EUR thousand \\
\hline $\mathrm{PbT}$ & Profit/loss before tax, EUR thousand \\
\hline $\mathrm{PaT}$ & Profit/loss after tax, EUR thousand \\
\hline CurrAsset & Current assets, EUR thousand \\
\hline WorkCap & Working capital, EUR thousand \\
\hline SharHoFund & Shareholders funds, EUR thousand \\
\hline DateInc & Date of incorporation \\
\hline IFO_eur & IFO index, economic climate, Euro zone \\
\hline Cap_Util_EWU & Capacity utilization, in percent, Euro zone (16) \\
\hline Prod_EWU_total & $\begin{array}{l}\text { Industrial production index (total manufacturing), } \\
\text { Euro zone (16) }\end{array}$ \\
\hline Prod_EWU_IM & $\begin{array}{l}\text { Industrial production index (intermediate goods), } \\
\text { Euro zone (16) }\end{array}$ \\
\hline Prod_EWU_Inv & $\begin{array}{l}\text { Industrial production index (investment goods), Euro } \\
\text { zone (16) }\end{array}$ \\
\hline
\end{tabular}

(to be continued) 
Table 2. List of variables (continued)

\begin{tabular}{|c|c|}
\hline Variable & Definition \\
\hline ISPO & $\begin{array}{l}\text { Immediate shareholder percentage of ownership } \\
\text { (numeric) }\end{array}$ \\
\hline Independence & $\begin{array}{l}\text { Dummy variable, by ImSharHold_Type and } \\
\text { Indep_Ind }\end{array}$ \\
\hline Manufacturing & Dummy variable, by NACE2 and Trade_Eng \\
\hline Wholesale & -“- \\
\hline Retail & -“- \\
\hline Service & 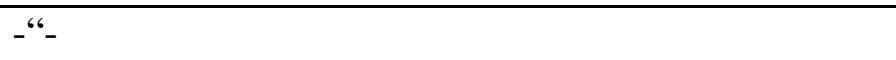 \\
\hline ResDev & -“- \\
\hline Tr45 & Dummy variable, by NACE2 \\
\hline Tr46 & Dummy variable, by NACE2 \\
\hline $\operatorname{Tr} 47$ & Dummy variable, by NACE2 \\
\hline Mfg30 & Dummy variable, by NACE2 \\
\hline Mfg20 & Dummy variable, by NACE2 \\
\hline Active_Ind & Dummy variable, Active/inactive \\
\hline$<$ Country $>$ & Dummy variable, by $<$ Country $>$ \\
\hline _IYear_<year> & Dummy variable, by <year> \\
\hline PaT_a3 & $\begin{array}{l}\text { 3-period moving average of PaT, } \\
(\mathrm{PaT}+\mathrm{l} . \mathrm{PaT}+\mathrm{l} 2 . \mathrm{PaT}) / 3\end{array}$ \\
\hline PaT_s3 & $\begin{array}{l}\text { 3-period moving standard deviation of PaT, (abs(PaT- } \\
\text { PaT_a3)+abs(l.PaT-PaT_a3)+abs(12.PaT-PaT_a3))/3 }\end{array}$ \\
\hline RoEbaT & $\begin{array}{l}\text { Return on equity (after tax, book value), PaT / } \\
\text { SharHoFund }\end{array}$ \\
\hline RoEbaT_a3 & $\begin{array}{l}\text { 3-period moving average of RoEbaT, } \\
(\text { RoEbaT+l.RoEbaT+l2.RoEbaT)/3 }\end{array}$ \\
\hline RoEbaT_s3 & $\begin{array}{l}\text { 3-period moving standard deviation of RoEbaT, } \\
\text { (abs(RoEbaT-RoEbaT_a3)+abs(l.RoEbaT- } \\
\text { RoEbaT_a3)+abs(12.RoEbaT-RoEbaT_a3))/3 }\end{array}$ \\
\hline RR3 & $\begin{array}{l}\text { 3-period relative moving standard deviation of } \\
\text { RoEbaT, RoEbaT_s3/ RoEbaT_a3 }\end{array}$ \\
\hline RoEbaT_a5 & 5-period moving average of RoEbaT \\
\hline RoEbaT_s5 & 5-period moving standard deviation of RoEbaT \\
\hline
\end{tabular}


Table 3.1. Summary statistics

\begin{tabular}{|c|c|c|c|c|c|}
\hline Variable & Obs & Mean & Std. Dev. & Min & Max \\
\hline BvD & 2405640 & 80188.5 & 46296.57 & 1 & 160376 \\
\hline Year & 2405644 & 2002 & 4.320509 & 1991 & 2009 \\
\hline NACE2 & 2311155 & 3690.095 & 1313.908 & 1000 & 4799 \\
\hline OpRev & 1011274 & 34968.65 & 844222.8 & 0 & $1.63 \mathrm{e}+08$ \\
\hline COGS & 1020057 & 26253.59 & 685004.3 & -2803821 & $1.53 \mathrm{e}+08$ \\
\hline OpExp & 1026773 & 6305.448 & 177073.8 & -525220 & $2.73 e+07$ \\
\hline EBIT & 1032254 & 1619.38 & 165562.5 & $-1.53 e+08$ & $1.16 \mathrm{e}+07$ \\
\hline PbT & 1028616 & 1713.042 & 170652 & $-1.53 e+08$ & $1.58 \mathrm{e}+07$ \\
\hline PaT & 1013210 & 1187.276 & 164691.8 & $-1.53 e+08$ & $1.60 \mathrm{e}+07$ \\
\hline CurrAsset & 1059193 & 3869.328 & 138118.5 & -65718 & $9.47 \mathrm{e}+07$ \\
\hline WorkCap & 1052973 & 5049.442 & 210450.9 & $-1.40 e+07$ & $8.95 e+07$ \\
\hline SharHoFund & 1067458 & 10169.02 & 407292.8 & -1186564 & $2.22 \mathrm{e}+08$ \\
\hline Denmark & 2405640 & .0166733 & .1280442 & 0 & 1 \\
\hline Estonia & 2405640 & .0217115 & .1457398 & 0 & 1 \\
\hline Finland & 2405640 & .0009291 & .0304664 & 0 & 1 \\
\hline France & 2405640 & .0007358 & .0271151 & 0 & 1 \\
\hline Germany & 2405640 & .0027124 & .0520098 & 0 & 1 \\
\hline Greece & 2405640 & .0649723 & .2464771 & 0 & 1 \\
\hline Iceland & 2405640 & .0007295 & .0270001 & 0 & 1 \\
\hline Ireland & 2405640 & .0023507 & .0484273 & 0 & 1 \\
\hline Latvia & 2405640 & .0118097 & .1080291 & 0 & 1 \\
\hline Liechtenst $\sim$ n & 2405640 & $6.24 \mathrm{e}-06$ & .0024971 & 0 & 1 \\
\hline Lithuania & 2405640 & .0129009 & .1128473 & 0 & 1 \\
\hline Malta & 2405640 & .0003118 & .0176542 & 0 & 1 \\
\hline Moldova & 2405640 & .001509 & .0388159 & 0 & 1 \\
\hline Netherlands & 2405640 & .0053749 & .0731162 & 0 & 1 \\
\hline Poland & 2405640 & .0173841 & .1306979 & 0 & 1 \\
\hline Portugal & 2405640 & .1358059 & .3425824 & 0 & 1 \\
\hline Russian_Fed & 2405640 & .4464571 & .497125 & 0 & 1 \\
\hline Sweden & 2405640 & .0190053 & .1365436 & 0 & 1 \\
\hline $\mathbf{C H}$ & 2405640 & .0003429 & .0185156 & 0 & 1 \\
\hline Ukraine & 2405640 & .1460443 & .3531507 & 0 & 1 \\
\hline UK & 2405640 & .0922333 & .289355 & 0 & 1 \\
\hline Independence & 2405640 & .5093967 & .4999118 & 0 & 1 \\
\hline
\end{tabular}


Table 3.1. Summary statistics (continued)

\begin{tabular}{|l|l|l|l|l|l|}
\hline Variable & Obs & Mean & Std. Dev. & Min & Max \\
\hline Mfg10 & 2405640 & .1447349 & .3518334 & 0 & 1 \\
\hline Tr45 & 2405640 & .0629708 & .2429104 & 0 & 1 \\
\hline Mfg30 & 2405640 & .0287948 & .1672295 & 0 & 1 \\
\hline Manufactur g & 2405640 & .3767022 & .4845593 & 0 & 1 \\
\hline Retail & 2405640 & .16808 & .3739374 & 0 & 1 \\
\hline Wholesale & 2405640 & .410529 & .4919299 & 0 & 1 \\
\hline ResDev & 2405640 & .0112797 & .1056055 & 0 & 1 \\
\hline Service & 2405640 & .0327044 & .1778618 & 0 & 1 \\
\hline Active_Ind & 2405640 & .9679815 & .1760492 & 0 & 1 \\
\hline & & & & & \\
\hline IFO_eur & 2405644 & 90.4237 & 14.28439 & 57.83898 & 116.5254 \\
\hline Cap_Util_EWU & 2405644 & 81.42 & 2.935121 & 71.3 & 84.2 \\
\hline Prod_EWU_t I & 2405644 & 95.69111 & 7.489539 & 77.37417 & 108.9467 \\
\hline Prod_EWU_IM & 2405644 & 95.26112 & 7.830695 & 75.84333 & 108.6858 \\
\hline Prod_EWU_Inv & 2405644 & 94.61495 & 10.35161 & 70.60667 & 113.115 \\
\hline & & & & & \\
\hline RoEbaT & 980671 & -.2026746 & 852.2335 & -824357.6 & 176755.9 \\
\hline RoEbaT_a3 & 584945 & .4730202 & 80.00559 & -2086.45 & 58920.04 \\
\hline RoEbaT_s3 & 584945 & .9098211 & 106.3689 & 0 & 78557.27 \\
\hline RR3 & 581989 & 767.4959 & 585805 & $-1.34 \mathrm{e}+08$ & $1.97 \mathrm{e}+08$ \\
\hline PaT_a3 & 615041 & 1489.154 & 47648.75 & -1703807 & 7485862 \\
\hline PaT_s3 & 615041 & 789.3758 & 24976.43 & 0 & 7042040 \\
\hline RoEbaT_a5 & 337035 & .4003556 & 62.63181 & -1251.609 & 35352.16 \\
\hline RoEbaT_s5 & 337035 & .9386527 & 99.90493 & 0 & 56561.51 \\
\hline
\end{tabular}


Table 3.2. Correlations profit and capital variables

\begin{tabular}{|l|l|l|l|l|}
\hline & OpProfit & EBIT & PbT & PaT \\
\hline OpProfit & 1.0000 & & & \\
\hline EBIT & 1.0000 & 1.0000 & & \\
\hline PbT & 0.9904 & 0.9904 & 1.0000 & \\
\hline PaT & 0.9847 & 0.9847 & 0.9932 & 1.0000 \\
\hline
\end{tabular}

\begin{tabular}{|l|l|l|l|}
\hline & CurrAsset & WorkCap & SharHoFund \\
\hline CurrAsset & 1.0000 & & \\
\hline WorkCap & 0.7996 & 1.0000 & \\
\hline SharHoFund & 0.6603 & 0.5658 & 1.0000 \\
\hline
\end{tabular}


Table 4.1. Results summary: profits after taxes

\begin{tabular}{|c|c|c|c|c|}
\hline Model & (1) & (2) & (3) & (4) \\
\hline Dep. Variable & PaT & PaT & PaT_a3 & PaT_a3 \\
\hline PaT_s3 & $.3150263 * * *$ & $.6423641 * * *$ & $.4857649 * * *$ & $.5818913 * * *$ \\
\hline SharHoFund & $.1691198 * * *$ & & $.1222436 * * *$ & \\
\hline CurrAsset & $-.1571605^{* * *}$ & & $-.057165 * * *$ & \\
\hline WorkCap & $.0069391^{* * *}$ & & $.0182809 * * *$ & \\
\hline NACE2 & $-.2492013^{*}$ & & $-.3479346 * *$ & \\
\hline Year & 790.6337 & & $342.9812 * * *$ & \\
\hline Independence & -373.6141 & & -246.903 & \\
\hline Retail & 643.9122 & & $1032.424^{* *}$ & \\
\hline Wholesale & $942.1419 * *$ & & $1195.509 * * *$ & \\
\hline ResDev & $3339.187 * * *$ & & $3005.011 * * *$ & \\
\hline Service & $-1092.534^{*}$ & & $-1466.138^{* *}$ & \\
\hline Active_Ind & -520.549 & & -387.2612 & \\
\hline DateInc & -8.670241 & & $19.1599 * * *$ & \\
\hline IFO_eur & $50.50429 *$ & & $36.23006^{* * *}$ & \\
\hline Cap_Util_EWU & 352.8594 & & 114.7451 & \\
\hline Prod_EWU_total & -1164.381 & & 180.5074 & \\
\hline Prod_EWU_IM & 144.1346 & & -532.1258 & \\
\hline Prod_EWU_Inv & 456.2698 & & 128.461 & \\
\hline Observations & 342186 & 615041 & 342186 & 615041 \\
\hline Groups (Firms) & 68816 & 135340 & 68816 & 135340 \\
\hline R-sq. within & 0.1041 & 0.0261 & 0.4031 & 0.2084 \\
\hline R-sq. between & 0.6720 & 0.3864 & 0.6481 & 0.3965 \\
\hline R-sq. overall & 0.4922 & 0.1999 & 0.6093 & 0.3077 \\
\hline Prob > chi2 & 0.0000 & 0.0000 & 0.0000 & 0.0000 \\
\hline
\end{tabular}

Note. (i) All models estimated with random effects. (ii) All equations include a constant. (iii) *** denotes significant at the $1 \%$, ** at the $5 \%$, * at the $10 \%$ level. 
Table 4.2. Results summary: return on shareholder funds - RE/FE models

\begin{tabular}{|c|c|c|c|}
\hline Model & (5) & (6) & (7) fixed effects \\
\hline Dep. Variable & RoEbaT_a3 & RoEbaT_a3 & RoEbaT_a3 \\
\hline RoEbaT_s3 & & $.739143^{* * *}$ & $.7404886 * * *$ \\
\hline Year & 0496019 & & \\
\hline NACE2 & $-.0005447 *$ & & \\
\hline OpRev & $5.34 \mathrm{e}-07$ & & \\
\hline COGS & $-4.86 e-07$ & & \\
\hline OpExp & $-7.54 \mathrm{e}-07$ & & \\
\hline CurrAsset & $-3.80 e-07$ & & \\
\hline WorkCap & $-1.09 \mathrm{e}-07$ & & \\
\hline France & -.1103064 & & \\
\hline Germany & 5.907157 & & \\
\hline Greece & -.2940051 & & \\
\hline Ireland & .0324365 & & \\
\hline Netherlands & .9539049 & & \\
\hline Poland & -.062561 & & \\
\hline Portugal & -.3295639 & & \\
\hline Russian_Fed & .8487541 & & \\
\hline Sweden & -.018641 & & \\
\hline $\mathbf{C H}$ & .2320946 & & \\
\hline Ukraine & -.0166807 & & \\
\hline UK & .2610084 & & \\
\hline Independence & .2685334 & & \\
\hline Manufactur g & -1.040702 & & \\
\hline Retail & .1369163 & & \\
\hline Wholesale & .1522806 & & \\
\hline ResDev & -.1524406 & & \\
\hline Service & .1868506 & & \\
\hline Active_Ind & .313417 & & \\
\hline DateInc & .0100055 & & \\
\hline IFO_eur & -.0644427 & & \\
\hline Cap_Util_EWU & .9497316 & & \\
\hline Prod_EWU_t $\sim$ I & 1.163247 & & \\
\hline Prod_EWU_IM & -.6437047 & & \\
\hline Prod_EWU_Inv & -.4892717 & & \\
\hline Observations & 333561 & 584945 & 584945 \\
\hline Groups (Firms) & 68503 & 130841 & 130841 \\
\hline R-sq. within & 0.0000 & 0.9730 & 0.9730 \\
\hline R-sq. between & 0.0004 & 0.8790 & 0.8790 \\
\hline R-sq. overall & 0.0001 & 0.9618 & 0.9618 \\
\hline Prob $>$ chi2 $(>F)$ & 0.9534 & 0.0000 & 0.0000 \\
\hline
\end{tabular}

Note. (i) Models (5) and (6) estimated with random effects; Model (7) estimated with fixed effects.

(ii) All equations include a constant. (iii) $* * *$ denotes significant at the $1 \%, * *$ at the $5 \%, *$ at the $10 \%$ level. 
Table 4.3. Results summary: return on shareholder funds - IV models

\begin{tabular}{|l|c|c|c|}
\hline \multicolumn{1}{|c|}{ Model } & (8) & (9) & (10) \\
\hline Dep. Variable & RoEbaT_a3 & RoEbaT_a3 & RoEbaT_a3 \\
\hline & & & \\
\hline RoEbaT_s3 & $.7531308^{* * *}$ & $.7613355^{* * *}$ & $.7618823^{* * *}$ \\
\hline OpRev & & $6.17 \mathrm{e}-07$ & \\
\hline COGS & & $-5.69 \mathrm{e}-07$ & \\
\hline OpExp & & $-7.17 \mathrm{e}-07$ & \\
\hline CurrAsset & & $-2.40 \mathrm{e}-07$ & \\
\hline WorkCap & & $1.28 \mathrm{e}-08$ & \\
\hline SharHoFund & & $-2.82 \mathrm{e}-08$ & \\
\hline Germany & $4.385667^{* * *}$ & & \\
\hline Russian_Fed & $-.421388^{* * *}$ & & \\
\hline UK & .0320813 & & \\
\hline Independence & .1308139 & & \\
\hline Retail & .0913744 & & \\
\hline Service & .009429 & & \\
\hline DateInc & -.0002586 & & \\
\hline IFO_eur & & & \\
\hline & & & \\
\hline & & & \\
\hline Observations & 344956 & 5764945 \\
\hline Groups (Firms) & 69792 & 130222 & 0.9730 \\
\hline R-sq. within & 0.9797 & 0.9745 & \\
\hline R-sq. between & 0.8698 & 0.8849 & \\
\hline R-sq. overall & 0.9689 & 0.9644 & \\
\hline Prob > chi2 (>F) & 0.0000 & & \\
\hline & & & \\
\hline
\end{tabular}

Note. (i) All models G2SLS RE IV regressions with RoEbaT_s3 instrumented by lagged values of RoEbaT and other variables. (ii) All equations include a constant. (iii) *** denotes significant at the $1 \%$, ** at the $5 \%, *$ at the $10 \%$ level. 
Table 5.1. Model (1) estimation and results

. xtreg PaT SharHoFund CurrAsset WorkCap NACE2 Year Independence Retail Wholesale ResDev Service Active_Ind DateInc IFO_eur Cap_Util_EWU Prod_EWU_total Prod_EWU_IM Prod_EWU_Inv PaT_s3,re

Random-effects GLS regression Group variable: BvD

$$
\begin{aligned}
\text { R-sq: } & \text { within }=0.1041 \\
& \text { between }=0.6720 \\
& \text { overall }=0.4922
\end{aligned}
$$

Random effects $\mathrm{u} \_\mathrm{i} \sim$ Gaussian $\operatorname{corr}\left(\mathrm{u} \_\mathrm{i}, \mathrm{X}\right) \quad=0$ (assumed)
Number of obs $=342186$

Number of groups $=68816$

Obs per group: $\min =\quad 1$

$\operatorname{avg}=5.0$

$\max =8$

$$
\text { Wald chi2(19) }=228587.32
$$$$
\text { Prob }>\text { chi } 2=0.0000
$$

\begin{tabular}{|l|l|l|l|l|l|l|}
\hline PaT & Coef. & Std. Err. & $\mathrm{z}$ & $\mathrm{P}>\mathrm{z}$ & $\begin{array}{l}{[95 \%} \\
\text { Conf. }\end{array}$ & Interval] \\
\hline & & & & & & \\
\hline SharHoFund & .1691198 & .0006235 & 271.23 & 0.000 & .1678977 & .1703418 \\
\hline CurrAsset & -.1571605 & .0018594 & -84.52 & 0.000 & -.1608048 & -.1535161 \\
\hline WorkCap & .0069391 & .0004566 & 15.20 & 0.000 & .0060442 & .007834 \\
\hline NACE2 & -.2492013 & .1467925 & -1.70 & 0.090 & -.5369094 & .0385068 \\
\hline Year & 790.6337 & 277.4237 & 2.85 & 0.004 & 246.8933 & 1334.374 \\
\hline Independence & -373.6141 & 228.4506 & -1.64 & 0.102 & -821.3691 & 74.14086 \\
\hline Retail & 643.9122 & 443.7828 & 1.45 & 0.147 & -225.8861 & 1513.71 \\
\hline Wholesale & 942.1419 & 391.5091 & 2.41 & 0.016 & 174.7981 & 1709.486 \\
\hline ResDev & 3339.187 & 726.1058 & 4.60 & 0.000 & 1916.046 & 4762.328 \\
\hline Service & -1092.534 & 640.002 & -1.71 & 0.088 & -2346.915 & 161.8472 \\
\hline Active_Ind & -520.549 & 466.6954 & -1.12 & 0.265 & -1435.255 & 394.1572 \\
\hline DateInc & -8.670241 & 5.932272 & -1.46 & 0.144 & -20.29728 & 2.956798 \\
\hline IFO_eur & 50.50429 & 28.62581 & 1.76 & 0.078 & -5.601266 & 106.6098 \\
\hline Cap_Util_EWU & 352.8594 & 392.7304 & 0.90 & 0.369 & -416.8781 & 1122.597 \\
\hline Prod_EWU_t l & -1164.381 & 1313.048 & -0.89 & 0.375 & -3737.908 & 1409.146 \\
\hline Prod_EWU_IM & 144.1346 & 704.5188 & 0.20 & 0.838 & -1236.697 & 1524.966 \\
\hline Prod_EWU_Inv & 456.2698 & 524.1343 & 0.87 & 0.384 & -571.0146 & 1483.554 \\
\hline PaT_s3 & .3150249 & .0031922 & 98.69 & 0.000 & .3087683 & .3212815 \\
\hline cons & -1543091 & 560683.5 & -2.75 & 0.006 & -2642011 & -444171.8 \\
\hline
\end{tabular}


Table 5.2. Model (2) estimation and results

. xtreg PaT PaT_s3,re

Random-effects GLS regression

Group variable: BvD

$$
\begin{aligned}
& \text { R-sq: } \text { within }=0.0261 \\
& \text { between }=0.3864 \\
& \text { overall }=0.1999
\end{aligned}
$$

Random effects $\mathrm{u} \_\mathrm{i} \sim$ Gaussian corr(u_i, X) $=0$ (assumed)
Number of obs $=615041$

Number of groups $=135340$

Obs per group: $\min =\quad 1$

$$
\operatorname{avg}=4.5
$$$$
\max =8
$$

Wald chi2(1) $=62054.63$

Prob $>$ chi2 $=0.0000$

\begin{tabular}{|l|l|l|l|l|l|l|}
\hline PaT & Coef. & Std. Err. & $\mathrm{z}$ & $\mathrm{P}>\mathrm{z}$ & $\begin{array}{l}{[95 \%} \\
\text { Conf. }\end{array}$ & Interval] \\
\hline & & & & & & \\
\hline PaT_s3 & .6423641 & .0025787 & 249.11 & 0.000 & .63731 & .6474182 \\
\hline _cons & 932.8439 & 85.58743 & 10.90 & 0.000 & 765.0956 & 1100.592 \\
\hline
\end{tabular}

sigma_u | 22244.375

sigma_e | 35546.18

rho | 28140822 (fraction of variance due to $u_{-}$i) 
Table 5.3. Model (3) estimation and results

. xtreg PaT_a3 SharHoFund CurrAsset WorkCap NACE2 Year Independence Retail Wholesale ResDev Service Active_Ind DateInc IFO_eur Cap_Util_EWU Prod_EWU_total Prod_EWU_IM Prod_EWU_Inv PaT_s3,re

Random-effects GLS regression

Group variable: BvD

R-sq: within $=0.4031$

between $=0.6481$

overall $=0.6093$

Random effects $\mathrm{u} \_\mathrm{i} \sim$ Gaussian corr $\left(\mathrm{u} \_\mathrm{i}, \mathrm{X}\right) \quad=0$ (assumed)

$$
\begin{array}{rr}
\text { Number of obs }= & 342186 \\
\text { Number of groups }= & 68816 \\
\text { Obs per group: } \min = & 1 \\
\text { avg }= & 5.0 \\
\max = & 8
\end{array}
$$

$$
\begin{array}{ll}
\text { Wald chi2(18) } & =313456.34 \\
\text { Prob }>\text { chi2 } & =0.0000
\end{array}
$$

\begin{tabular}{|l|l|l|l|l|l|l|}
\hline PaT_a3 & Coef. & Std. Err. & $\mathrm{z}$ & $\mathrm{P}>\mathrm{z}$ & $\begin{array}{l}{[95 \%} \\
\text { Conf. }\end{array}$ & Interval] \\
\hline & & & & & & \\
\hline SharHoFund & .1222436 & .0004285 & 285.29 & 0.000 & .1214038 & .1230835 \\
\hline CurrAsset & -.057165 & .0012828 & -44.56 & 0.000 & -.0596793 & -.0546506 \\
\hline WorkCap & .0182809 & .0002172 & 84.16 & 0.000 & .0178552 & .0187067 \\
\hline NACE2 & -.3479346 & .1537317 & -2.26 & 0.024 & -.6492431 & -.0466261 \\
\hline Year & 342.9812 & 127.4334 & 2.69 & 0.007 & 93.21638 & 592.746 \\
\hline Independence & -246.903 & 232.1537 & -1.06 & 0.288 & -701.916 & 208.11 \\
\hline Retail & 1032.424 & 459.9427 & 2.24 & 0.025 & 130.9532 & 1933.896 \\
\hline Wholesale & 1195.509 & 411.1747 & 2.91 & 0.004 & 389.6217 & 2001.397 \\
\hline ResDev & 3005.011 & 769.1606 & 3.91 & 0.000 & 1497.484 & 4512.538 \\
\hline Service & -1466.138 & 675.9434 & -2.17 & 0.030 & -2790.963 & -141.3135 \\
\hline Active_Ind & -387.2612 & 492.68 & -0.79 & 0.432 & -1352.896 & 578.3739 \\
\hline DateInc & 19.1599 & 6.21326 & 3.08 & 0.002 & 6.982136 & 31.33767 \\
\hline IFO_eur & 36.23006 & 12.99447 & 2.79 & 0.005 & 10.76136 & 61.69875 \\
\hline Cap_Util_EWU & 114.7451 & 176.2098 & 0.65 & 0.515 & -230.6197 & 460.1099 \\
\hline Prod_EWU_t l & 180.5074 & 595.9537 & 0.30 & 0.762 & -987.5404 & 1348.555 \\
\hline Prod_EWU_IM & -532.1258 & 324.191 & -1.64 & 0.101 & -1167.529 & 103.2769 \\
\hline Prod_EWU_Inv & 128.461 & 236.8455 & 0.54 & 0.588 & -335.7477 & 592.6697 \\
\hline PaT_s3 & .4857649 & .0016033 & 302.99 & 0.000 & .4826226 & .4889072 \\
\hline cons & -714980.2 & 257605.9 & -2.78 & 0.006 & -1219879 & -210081.9 \\
\hline
\end{tabular}

sigma_u | 26605.824

sigma_e | 20497.976

rho | .62752368 (fraction of variance due to u_i) 
Table 5.4. Model (4) estimation and results

.xtreg PaT_a3 PaT_s3,re

Random-effects GLS regression

Number of obs $=615041$

Group variable: BvD

Number of groups $=135340$

R-sq: within $=0.2084$

between $=0.3965$

Obs per group: $\min =\quad 1$

overall $=0.3077$

$\begin{array}{lr}\operatorname{avg}= & 4.5 \\ \max = & 8\end{array}$

Random effects $\mathrm{u} \_\mathrm{i} \sim$ Gaussian

Wald chi2(1) $\quad=169090.12$

corr(u_i, X) = 0 (assumed)

Prob $>$ chi2 $=0.0000$

\begin{tabular}{|l|l|l|l|l|l|l|}
\hline PaT_a3 & Coef. & Std. Err. & $\mathrm{z}$ & $\mathrm{P}>\mathrm{z}$ & $\begin{array}{l}{[95 \%} \\
\text { Conf. }\end{array}$ & Interval] \\
\hline & & & & & & \\
\hline PaT_s3 & .5818913 & .0014151 & 411.21 & 0.000 & .5791178 & .5846648 \\
\hline _cons & 735.6148 & 79.05327 & 9.31 & 0.000 & 580.6733 & 890.5564 \\
\hline
\end{tabular}

sigma_u | 25901.808

sigma_e| 18257.522

rho | .66807053 (fraction of variance due to $u_{-} i$ ) 
Table 5.5. Model (5) estimation and results

. xtreg RoEbaT_a3 Year NACE2 OpRev COGS OpExp CurrAsset WorkCap France Germany Greece Ireland Netherlands Poland Portugal Russian_Fed Sweden CH Ukraine UK Independence Manufacturing Retail Wholesale ResDev Service Active_Ind DateInc IFO_eur Cap_Util_EWU Prod_EWU_total Prod_EWU_IM Prod_EWU_Inv,re

Random-effects GLS regression Group variable: BvD

$$
\begin{aligned}
& \text { R-sq: } \text { within }=0.0000 \\
& \text { between }=0.0004 \\
& \text { overall }=0.0001
\end{aligned}
$$

Random effects u_i Gaussian corr(u_i, X) = 0 (assumed)

$$
\begin{array}{rr}
\text { Number of obs }= & 333561 \\
\text { Number of groups }= & 68503 \\
\text { Obs per group: } \min = & 1 \\
\text { avg }= & 4.9 \\
\max = & 8
\end{array}
$$

\begin{tabular}{|c|c|c|c|c|c|c|}
\hline RoEbaT_a3 & Coef. & Std. Err. & $\mathrm{Z}$ & $\mathrm{P}>\mathrm{Z}$ & [95\% Conf. & Interval] \\
\hline Year & .0496019 & .5931254 & 0.08 & 0.933 & -1.112903 & 1.212106 \\
\hline NACE2 & -.0005447 & .0003036 & -1.79 & 0.073 & -.0011397 & .0000504 \\
\hline OpRev & $5.34 \mathrm{e}-07$ & $2.90 \mathrm{e}-06$ & 0.18 & 0.854 & $-5.16 e-06$ & $6.22 \mathrm{e}-06$ \\
\hline COGS & $-4.86 e-07$ & $2.95 \mathrm{e}-06$ & -0.16 & 0.869 & $-6.27 e-06$ & $5.30 \mathrm{e}-06$ \\
\hline OpExp & $-7.54 \mathrm{e}-07$ & $4.11 \mathrm{e}-06$ & -0.18 & 0.854 & $-8.81 e-06$ & 7.30e-06 \\
\hline CurrAsset & $-3.80 \mathrm{e}-07$ & $4.21 \mathrm{e}-06$ & -0.09 & 0.928 & $-8.62 e-06$ & $7.86 \mathrm{e}-06$ \\
\hline WorkCap & $-1.09 \mathrm{e}-07$ & 9.43e-07 & -0.12 & 0.908 & $-1.96 e-06$ & $1.74 \mathrm{e}-06$ \\
\hline France & -.1103064 & 3.710988 & -0.03 & 0.976 & -7.383709 & 7.163096 \\
\hline Germany & 5.907157 & 3.245669 & 1.82 & 0.069 & -.4542385 & 12.26855 \\
\hline Greece & -.2940051 & .8374065 & -0.35 & 0.726 & -1.935292 & 1.347281 \\
\hline Ireland & .0324365 & 3.096087 & 0.01 & 0.992 & -6.035783 & 6.100656 \\
\hline Netherlands & .9539049 & 1.964913 & 0.49 & 0.627 & -2.897253 & 4.805063 \\
\hline Poland & -.062561 & 1.347777 & -0.05 & 0.963 & -2.704156 & 2.579034 \\
\hline Portugal & -.3295639 & .8153737 & -0.40 & 0.686 & -1.927667 & 1.268539 \\
\hline Russian_Fed & .8487541 & .8468052 & 1.00 & 0.316 & -.8109536 & 2.508462 \\
\hline Sweden & -.018641 & 1.057636 & -0.02 & 0.986 & -2.091569 & 2.054287 \\
\hline $\mathrm{CH}$ & .2320946 & 5.794207 & 0.04 & 0.968 & -11.12434 & 11.58853 \\
\hline Ukraine & -.0166807 & .9590869 & -0.02 & 0.986 & -1.896456 & 1.863095 \\
\hline UK & .2610084 & .8430097 & 0.31 & 0.757 & -1.39126 & 1.913277 \\
\hline Independence & .2685334 & .3863236 & 0.70 & 0.487 & -.4886469 & 1.025714 \\
\hline Manufactur g & -1.040702 & .9081344 & -1.15 & 0.252 & -2.820613 & .7392083 \\
\hline Retail & .1369163 & .7713802 & 0.18 & 0.859 & -1.374961 & 1.648794 \\
\hline Wholesale & .1522806 & .6872482 & 0.22 & 0.825 & -1.194701 & 1.499262 \\
\hline ResDev & -.1524406 & 1.151754 & -0.13 & 0.895 & -2.409836 & 2.104955 \\
\hline Service & .1868506 & 1.007281 & 0.19 & 0.853 & -1.787383 & 2.161084 \\
\hline Active_Ind & .313417 & .949335 & 0.33 & 0.741 & -1.547245 & 2.174079 \\
\hline DateInc & .0100055 & .0098322 & 1.02 & 0.309 & -.0092653 & .0292764 \\
\hline IFO_eur & -.0644427 & .06186 & -1.04 & 0.298 & -.1856861 & .0568007 \\
\hline Cap_Util_EWU & .9497316 & .8570719 & 1.11 & 0.268 & -.7300985 & 2.629562 \\
\hline Prod_EWU_t l & 1.163247 & 2.817218 & 0.41 & 0.680 & -4.358399 & 6.684892 \\
\hline Prod_EWU_IM & -.6437047 & 1.499249 & -0.43 & 0.668 & -3.582179 & 2.294769 \\
\hline Prod_EWU_Inv & -.4892717 & 1.12757 & -0.43 & 0.664 & -2.699269 & 1.720726 \\
\hline _cons & -191.9444 & 1199.686 & -0.16 & 0.873 & -2543.285 & 2159.396 \\
\hline
\end{tabular}

Wald chi2(32) = 19.88

Prob $>$ chi2 $=0.9534$

sigma_u 0

sigma_e | 106.33263

rho $\quad 0$ (fraction of variance due to $u \_i$ ) 
Table 5.6. Model (6) estimation and results

.xtreg RoEbaT_a3 RoEbaT_s3,re

Random-effects GLS regression N N N $\quad$ Number of obs 584945

Group variable: BvD

Number of groups $=130841$

R-sq: within $=0.9730$

between $=0.8790$

Obs per group: $\min =\quad 1$

overall $=0.9618$

$\begin{array}{lr}\operatorname{avg}= & 4.5 \\ \max = & 8\end{array}$

Random effects u_i $\sim$ Gaussian

Wald chi2(1) $=1.72 \mathrm{e}+07$

$\operatorname{corr}\left(\mathrm{u} \_\mathrm{i}, \mathrm{X}\right) \quad=0$ (assumed)

Prob $>$ chi2 $=0.0000$

\begin{tabular}{|l|l|l|l|l|l|l|}
\hline RoEbaT_a3 & Coef. & Std. Err. & $\mathrm{z}$ & $\mathrm{P}>\mathrm{z}$ & $\begin{array}{l}{[95 \%} \\
\text { Conf. }\end{array}$ & Interval] \\
\hline & & & & & & \\
\hline RoEbaT_s3 & .739143 & .0001783 & 4146.03 & 0.000 & .7387936 & .7394924 \\
\hline cons & -.2062312 & .0276325 & -7.46 & 0.000 & -.2603899 & -.1520725 \\
\hline
\end{tabular}

sigma_u | 6.9255879

sigma_e | 13.481103

rho 20880693 (fraction of variance due to u_i) 
Table 5.7. Model (7) estimation and results

.xtreg RoEbaT_a3 RoEbaT_s3,fe

Fixed-effects (within) regression

Group variable: BvD

Number of obs $=584945$

R-sq: within $=0.9730$

between $=0.8790$

Number of groups $=130841$

overall $=0.9618$

Obs per group: $\min =1$

$$
\begin{array}{lr}
\operatorname{avg}= & 4.5 \\
\max = & 8
\end{array}
$$

$\begin{array}{lll}\text { corr }\left(u \_i, X b\right)=-0.0296 & F(1,454103) & =1.64 \mathrm{e}+07 \\ & \text { Prob }>F & =0.0000\end{array}$

\begin{tabular}{|l|l|l|l|l|l|l|}
\hline RoEbaT_a3 & Coef. & Std. Err. & $\mathrm{t}$ & $\mathrm{P}>\mathrm{t}$ & $\begin{array}{l}{[95 \%} \\
\text { Conf. }\end{array}$ & Interval] \\
\hline & & & & & & \\
\hline RoEbaT_s3 & .7404886 & .0001831 & 4044.73 & 0.000 & .7401298 & .7408474 \\
\hline cons & -.200692 & .0176274 & -11.39 & 0.000 & -.2352411 & -.1661429 \\
\hline
\end{tabular}

sigma_u | 10.718748

sigma_e | 13.481103

rho | 38732056 (fraction of variance due to u_i)

F test that all $u \_i=0: F(130840,454103)=2.54$ Prob $>F=0.0000$ 
Table 5.8. Model (8) estimation and results

. xtivreg RoEbaT_a3 Germany Russian_Fed UK Independence Retail Service DateInc l.IFO_eur (RoEbaT_s3 = RoEbaT l.RoEbaT 12.RoEbaT), re first

First-stage G2SLS regression

\begin{tabular}{|c|c|c|c|c|c|c|}
\hline & & $\begin{array}{l}\text { Number of obs } \\
\text { Wald chi(11) } \\
\text { Prob > chi2 }\end{array}$ & $\begin{array}{l}=344956 \\
=\quad 2.3 \mathrm{e}+07 \\
=0.0000\end{array}$ & & & \\
\hline RoEbaT_s3 & Coef. & Std. Err. & $\mathrm{z}$ & $\mathrm{P}>\mathrm{Z}$ & [95\% Conf. & Interval] \\
\hline Germany & 1.187542 & .736581 & 1.61 & 0.107 & -.2561302 & 2.631214 \\
\hline Russian_Fed & .645984 & .1388069 & 4.65 & 0.000 & .3739275 & .9180405 \\
\hline UK & .2061017 & 1392995 & 1.48 & 0.139 & -.0669203 & .4791238 \\
\hline Independence & -.2308548 & .1034365 & -2.23 & 0.026 & -.4335866 & -.0281231 \\
\hline Retail & -.0727917 & .1309406 & -0.56 & 0.578 & -.3294305 & .1838471 \\
\hline Service & .2290313 & .2892477 & 0.79 & 0.428 & -.3378838 & .7959465 \\
\hline DateInc & .0058316 & .0026575 & 2.19 & 0.028 & .000623 & .0110402 \\
\hline \multicolumn{7}{|l|}{ IFO_eur } \\
\hline L1. & -.0010325 & .0024964 & -0.41 & 0.679 & -.0059254 & .0038603 \\
\hline \multicolumn{7}{|l|}{ RoEbaT } \\
\hline.-- & .0633732 & .0014707 & 43.09 & 0.000 & .0604908 & .0662557 \\
\hline L1. & -.1238788 & .0015089 & -82.10 & 0.000 & -.1268362 & -.1209213 \\
\hline $\mathrm{L} 2$. & .4420455 & .0000926 & 4775.38 & 0.000 & .4418641 & .4422269 \\
\hline _cons & -10.94784 & 5.289392 & -2.07 & 0.038 & -21.31486 & -.5808254 \\
\hline
\end{tabular}

G2SLS random-effects IV regression Group variable:

R-sq: within $=0.9797$ between $=0.8698$ overall $=0.9689$

corr $($ u_i, X) $=0$ (assumed)
Number of obs $=344956$

Number of groups $=69792$

Obs per group: $\min =1$

$\operatorname{avg}=4.9$

$\max =8$

Wald chi2(9) $\quad=1.40 \mathrm{e}+07$

Prob $>$ chi $\quad=0.0000$

\begin{tabular}{|l|l|l|l|l|l|l|}
\hline RoEbaT_a3 & Coef. & Std. Err. & $\mathrm{z}$ & $\mathrm{P}>\mathrm{z}$ & {$[95 \%$ Conf. } & Interval] \\
\hline & & & & & & \\
\hline RoEbaT_s3 & .7531308 & .0002013 & 3740.77 & 0.000 & .7527362 & .7535254 \\
\hline Germany & 4.385667 & .7081678 & 6.19 & 0.000 & 2.997684 & 5.773651 \\
\hline Russian_Fed & -.421388 & .1334807 & -3.16 & 0.002 & -.6830053 & -.1597707 \\
\hline UK & .0320813 & .1339533 & 0.24 & 0.811 & -.2304623 & .2946248 \\
\hline Independence & .1308139 & .0994673 & 1.32 & 0.188 & -.0641384 & .3257662 \\
\hline Retail & .0913744 & .125916 & 0.73 & 0.468 & -.1554164 & .3381653 \\
\hline Service & .009429 & .2781481 & 0.03 & 0.973 & -.5357312 & .5545892 \\
\hline DateInc & -.0002586 & .0025555 & -0.10 & 0.919 & -.0052674 & .0047501 \\
\hline IFO_eur & & & & & \\
\hline L1. & .0021687 & .0024006 & 0.90 & 0.366 & -.0025364 & .0068738 \\
\hline _cons & .0561135 & 5.086377 & 0.01 & 0.991 & -9.913002 & 10.02523 \\
\hline
\end{tabular}

sigma_u | 9.9607548

sigma_e | 14.92439

rho | 30817018 (fraction of variance due to u_i)

Instrumented: RoEbaT_s3

Instruments: Germany Russian_Fed UK Independence Retail Service DateInc L.IFO_eur RoEbaT L.RoEbaT L2.RoEbaT 
Table 5.9. Model (9) estimation and results

. xtivreg RoEbaT_a3 OpRev COGS OpExp CurrAsset WorkCap SharHoFund (RoEbaT_s3 = RoEbaT l.RoEbaT 12.RoEbaT), re first

First-stage G2SLS regression

$$
\begin{array}{lll}
\text { Number of obs } & =576622 \\
\text { Wald chi }(9) & =2.0 \mathrm{e}+07 \\
\text { Prob }>\text { chi2 } & =0.0000
\end{array}
$$

\begin{tabular}{|l|l|l|l|l|l|l|}
\hline RoEbaT_s3 & Coef. & Std. Err. & $\mathrm{z}$ & $\mathrm{P}>\mathrm{z}$ & {$[95 \%$ Conf. } & Interval] \\
\hline & & & & & & \\
\hline OpRev & $-4.33 \mathrm{e}-07$ & $6.87 \mathrm{e}-07$ & -0.63 & 0.529 & $-1.78 \mathrm{e}-06$ & $9.15 \mathrm{e}-07$ \\
\hline COGS & $4.18 \mathrm{e}-07$ & $6.90 \mathrm{e}-07$ & 0.61 & 0.544 & $-9.34 \mathrm{e}-07$ & $1.77 \mathrm{e}-06$ \\
\hline OpExp & $6.21 \mathrm{e}-07$ & $8.84 \mathrm{e}-07$ & 0.70 & 0.482 & $-1.11 \mathrm{e}-06$ & $2.35 \mathrm{e}-06$ \\
\hline CurrAsset & $6.65 \mathrm{e}-08$ & $1.08 \mathrm{e}-06$ & 0.06 & 0.951 & $-2.04 \mathrm{e}-06$ & $2.17 \mathrm{e}-06$ \\
\hline WorkCap & $-7.81 \mathrm{e}-09$ & $1.72 \mathrm{e}-07$ & -0.05 & 0.964 & $-3.45 \mathrm{e}-07$ & $3.29 \mathrm{e}-07$ \\
\hline SharHoFund & $-8.74 \mathrm{e}-08$ & $2.93 \mathrm{e}-07$ & -0.30 & 0.766 & $-6.62 \mathrm{e}-07$ & $4.87 \mathrm{e}-07$ \\
\hline RoEbaT & & & & & & \\
\hline.-- & .3612711 & .0006823 & 529.51 & 0.000 & .3599339 & .3626083 \\
\hline L1. & .3177225 & .0006773 & 469.09 & 0.000 & .316395 & .31905 \\
\hline L2. & .4399816 & .0000991 & 4441.82 & 0.000 & .4397874 & .4401757 \\
\hline cons & .3799265 & .0380757 & 9.98 & 0.000 & .3052995 & .4545535 \\
\hline
\end{tabular}

G2SLS random-effects IV regression

Group variable: BvD

R-sq: within $=0.9745$

between $=0.8849$

overall $=0.9644$

$\operatorname{corr}\left(\mathrm{u} \_\mathrm{i}, \mathrm{X}\right)=0$ (assumed)
Number of obs $\quad=576622$

Number of groups $=130222$

Obs per group: $\min =1$

avg $=4.4$

$\max =8$

Wald chi2(7) $\quad=1.87 \mathrm{e}+07$

Prob $>$ chi $2 \quad=0.0000$

\begin{tabular}{|l|l|l|l|l|l|l|}
\hline RoEbaT_a3 & Coef. & Std. Err. & $\mathrm{z}$ & $\mathrm{P}>\mathrm{z}$ & {$[95 \%$ Conf. } & Interval] \\
\hline & & & & & & \\
\hline RoEbaT_s3 & .7613355 & .0001761 & 4323.58 & 0.000 & .7609903 & .7616806 \\
\hline OpRev & $6.17 \mathrm{e}-07$ & $5.41 \mathrm{e}-07$ & 1.14 & 0.254 & $-4.44 \mathrm{e}-07$ & $1.68 \mathrm{e}-06$ \\
\hline COGS & $-5.69 \mathrm{e}-07$ & $5.43 \mathrm{e}-07$ & -1.05 & 0.295 & $-1.63 \mathrm{e}-06$ & $4.96 \mathrm{e}-07$ \\
\hline OpExp & $-7.17 \mathrm{e}-07$ & $6.96 \mathrm{e}-07$ & -1.03 & 0.303 & $-2.08 \mathrm{e}-06$ & $6.47 \mathrm{e}-07$ \\
\hline CurrAsset & $-2.40 \mathrm{e}-07$ & $8.47 \mathrm{e}-07$ & -0.28 & 0.777 & $-1.90 \mathrm{e}-06$ & $1.42 \mathrm{e}-06$ \\
\hline WorkCap & $1.28 \mathrm{e}-08$ & $1.35 \mathrm{e}-07$ & 0.09 & 0.925 & $-2.53 \mathrm{e}-07$ & $2.78 \mathrm{e}-07$ \\
\hline SharHoFund & $-2.82 \mathrm{e}-08$ & $2.31 \mathrm{e}-07$ & -0.12 & 0.903 & $-4.81 \mathrm{e}-07$ & $4.24 \mathrm{e}-07$ \\
\hline cons & -.224224 & .0299777 & -7.48 & 0.000 & -.2829792 & -.1654688 \\
\hline
\end{tabular}

sigma_u | 8.2983538

sigma_e | 13.345309

rho $\quad .27884148$ (fraction of variance due to u_i)

Instrumented: RoEbaT_s3

Instruments: OpRev COGS OpExp CurrAsset WorkCap SharHoFund RoEbaT L.RoEbaT L2.RoEbaT 
Table 5.10. Model (10) estimation and results

.xtivreg RoEbaT_a3 (RoEbaT_s3 = RoEbaT l.RoEbaT 12.RoEbaT), re first

First-stage G2SLS regression

$$
\begin{array}{lll}
\text { Number of obs } & =584945 \\
\text { Wald chi(3) } & =1.9 \mathrm{e}+07 \\
\text { Prob }>\text { chi2 } & =0.0000
\end{array}
$$

\begin{tabular}{|l|l|l|l|l|l|l|}
\hline RoEbaT_s3 & Coef. & Std. Err. & $\mathrm{z}$ & $\mathrm{P}>\mathrm{z}$ & $\begin{array}{l}{[95 \%} \\
\text { Conf. }\end{array}$ & Interval] \\
\hline & & & & & & \\
\hline RoEbaT & & & & & & \\
\hline.-- & .3446768 & .0006767 & 509.37 & 0.000 & .3433505 & .346003 \\
\hline L1. & .3155672 & .000687 & 459.35 & 0.000 & .3142207 & .3169136 \\
\hline L2. & .4398766 & .0001008 & 4362.47 & 0.000 & .439679 & .4400743 \\
\hline Cons & .3965918 & .0392706 & 10.10 & 0.000 & .3196228 & .4735608 \\
\hline
\end{tabular}

G2SLS random-effects IV regression Group variable: BvD

$$
\begin{aligned}
& \text { R-sq: } \text { within }=0.9730 \\
& \text { between }=0.8790 \\
& \text { overall }=0.9618
\end{aligned}
$$

$$
\operatorname{corr}\left(\mathrm{u} \_\mathrm{i}, \mathrm{X}\right)=0 \text { (assumed) }
$$

$$
\begin{array}{ll}
\text { Number of obs } & =584945 \\
\text { Number of groups } & =130841
\end{array}
$$

Obs per group: $\min =\quad 1$

$$
\begin{array}{lc}
\operatorname{avg}= & 4.5 \\
\max = & 8
\end{array}
$$

$$
\begin{array}{ll}
\text { Wald chi2(1) } & =1.79 \mathrm{e}+07 \\
\text { Prob }>\text { chi2 } & =0.0000
\end{array}
$$

\begin{tabular}{|l|l|l|l|l|l|l|}
\hline RoEbaT_a3 & Coef. & Std. Err. & $\mathrm{z}$ & $\mathrm{P}>\mathrm{z}$ & $\begin{array}{l}{[95 \%} \\
\text { Conf. }\end{array}$ & Interval] \\
\hline & & & & & & \\
\hline RoEbaT_s3 & .7618823 & .0001802 & 4228.85 & 0.000 & .7615292 & .7622354 \\
\hline _cons & -.2292628 & .0310601 & -7.38 & 0.000 & -.2901394 & -.1683862 \\
\hline
\end{tabular}

sigma_u | 8.7433885

sigma_e | 13.641844

rho . 2911742 (fraction of variance due to u_i) 